E-ISSN : 2549-6581

DOI: 10.21776/ub.JOIM.2020.004.03.3

Artikel Hasil Penelitian

Diterima : 05 Juli 2020

Direview : 15 September 2020

Dimuat : Desember 2020 - Maret 2021

\section{OPEN ACCESS}

Journal of Issues in Midwifer

\title{
Pengaruh Pemberian Ekstrak Kulit Buah Manggis (Garcinia mangostana L.) Menghambat Flexi Cranial Embrio Ayam Umur 48 Jam
}

\author{
Yessy Mulyanur Anggraeni ${ }^{{ }^{\star}}$, Bambang Rahardjo $^{2}$, Indriati Dwi Rahayu ${ }^{3}$ \\ ${ }^{\left.{ }^{*}\right)}$ Program Studi Sarjana Kebidanan Fakultas Kedokteran Universitas Brawijaya, Email: \\ yessyyhessay@gmail.com, Tlp : +6281359780009 \\ ${ }^{2}$ RSSA Malang, Email: bar_feto@yahoo.com \\ ${ }^{3}$ Program Studi Kedokteran Fakultas Kedokteran Universitas Brawijaya: Email: indri.fk@ub.ac.id
}

\begin{abstract}
Embryonic development forms three layers of germinativum that is endoderm, mesoderm and ectoderm. At the beginning of intrauterine fetus exchange of substances through diffusion, but in line with the development of the embryo, nutrition is not obtained through diffusion alone. Endoderm lining mesoderm cells will then be formed angioblasts as an early sign of vascularity. In the development of flexi cranial can be known from the development of the brain and heart which is characterized by bending the head of the embryo and decreased heart from the cranial down. The development of a normal vascular system will have an effect on organogenesis and morphogesis processes. If there are disturbances in the process of growth and development at that stage can cause congenital abnormalities. Xanthones mangosteen peel is rich in benefits, but in research on the effects of xanthones on embryos is still very limited and has not been able to explain their effects on the condition of the fetus. The study was conducted with the aim to determine the effect of mangosteen peel extract inhibiting the flexi cranial of 48 hours chicken embryos using doses of $100 \mu \mathrm{g} / \mathrm{mL}, 150 \mu \mathrm{g} / \mathrm{mL}$ and $200 \mu \mathrm{g} / \mathrm{mL}$. Mangosteen peel extract is injected into chicken eggs less than 7 days after oviposition then incubated for 48 hours. The results showed that mangosteen peel extract inhibited flexi cranial of chicken embryos with Chi-Square test results $(p=0.002)$. The conclusion of the study was that exposure to mangosteen peel extract inhibited flexi cranial and gave significant results.
\end{abstract}

Key words: Mangosteen peel, chicken embryo, in ovo, flexi cranial

\begin{abstract}
ABSTRAK
Perkembangan embrio membentuk tiga lapisan germativum yaitu endoderm, mesoderm, dan ektoderm. Di awal fetus intrauterin pertukaran zat melalui difusi, akan tetapi sejalan perkembangan embrio, nutrisi tidak didapakan melalui difusi saja. Sel-sel lapisan mesoderm akan diinduksi endoderm selanjutnya membentuk angioblas sebagai tanda awal terjadinya vaskuloangiogenesis. Pada perkembangan flexi cranial dapat diketahui dari perkembangan otak dan jantung yang ditandai dengan menekuknya kepala embrio dan penurunan jantung dari cranial ke bawah. Terjadinya perkembangan sistem vaskuler yang normal akan berpengaruh pada proses organogenesis dan morfogesis
\end{abstract}


yang maksimal. Apabila terdapat gangguan proses pertumbuhan dan perkembangan pada tahap tersebut dapat menyebabkan kelainan kongenital. Xanthone kulit buah manggis kaya akan manfaat, akan tetapi dalam penelitian mengenai efek xanthone pada embrio masih sangat terbatas dan belum dapat menjelaskan pengaruhnya terhadap kondisi janin. Penelitian dilakukan dengan tujuan untuk mengetahui efek pemberian ekstrak kulit buah manggis (Garcinia mangostana L.) menghambat flexi cranial embrio ayam umur 48 jam dengan menggunakan dosis $100 \mu \mathrm{g} / \mathrm{mL}, 150 \mu \mathrm{g} / \mathrm{mL}, 200 \mu \mathrm{g} / \mathrm{mL}$. Ekstrak kulit buah manggis diinjeksikan pada telur ayam berusia kurang dari 7 hari pasca oviposition kemudian dilakukan inkubasi selama 48 jam. Hasil penelitian menunjukkan bahwa ekstrak kulit buah manggis menghambat flexi cranial embrio ayam dengan hasil uji Chi-Square $(p=0,002)$. Kesimpulan dari penelitian adalah pemberian paparan ekstrak kulit buah manggis menghambat flexi cranial dan memberikan hasil yang signifikan.

Kata kunci: Kulit buah manggis, embrio ayam, in ovo, flexi cranial

*Korespondensi: Yessy Mulyanur Anggraeni. Surel: yessyyhessay@gmail.com

\section{PENDAHULUAN}

Pada saat kehamilan,
trimester pertama merupakan periode yang sangat penting dalam awal pembentukan embrio. Menurut data WHO menyebutkan bahwa diseluruh dunia lebih dari 8 juta bayi disetiap tahunnya lahir dengan kelainan kongenital. Di Amerika Serikat disetiap tahun mengalami bayi lahir dengan kelainan kongenital berjumlah hampir 120.000. Dari 2,68 juta kematian bayi, $11,3 \%$ dikarenakan oleh kelainan kongenital. Rikesdes tahun 2007 menjelaskan bahwa di Indonesia salah satu penyebab kematian bayi adalah kelainan kongenital. Kematian bayi pada usia 0-6 hari disebabkan kelainan kongenital sebesar $1,4 \%$ dan usia bayi 7-28 hari meningkat menjadi $18,1 \%$. Tahap ini sangat rentan terjadi kecacatan. Kelainan kongenital yang paling sering terjadi yaitu kelainan jantung bawaan, neural tube defect, dan Down Syndrome ${ }^{(1)}$.
Periode ini terjadi diferensiasi jaringan dalam pembentukan organ definitif. Lapisan germativum ektoderm membentuk seperti cakram yang lebih luas dibagian sefalik dibandingkan dengan kaudalnya pada saat awal minggu ke tiga. Kemudian munculnya notokorda dan mesoderm prekorda menginduksi ektoderm untuk menebal dan membentuk lempeng saraf (neural plate). Jaringan saraf berproliferasi dengan cepat bersama menutupnya tabung saraf (neural tube) serta flexi segmen anterior akan membentuk bagianbagian otak ${ }^{(2)}$. Saat yang bersamaan, sistem kardiovaskular terbentuk dari jaringan angioblastik berasal dari sel-sel mesenkim mesoderm. Jantung terbentuk pada 4 tahap diawali dari pembentukan buluh jantung (tubing), kemudian pembentukan jerat jantung/perputaran bakal jantung dan juga arteri besar (looping), selanjutnya diikuti pembentukan 
sekat jantung (septasi), dan yang terakhir pergeseran bagian jantung sebelum menjadi jantung sempurna (migrasi) $^{(3)}$. Jantung berdenyut, sehingga darah bersirkulasi melalui sistem vaskuler yang baru terbentuk walaupun struktur jantung belum terbentuk dengan sempurna. Dari kemajuan perkembangan otak serta jantung yang ditandai oleh menekuknya kepala embrio dan penurunan jantung dari cranial ke bawah disebut terjadinya flexi cranial. Terbentuk slight flexi cranial ditandai dengan menekuknya kepala ke depan dan posisi jantung juga mulai turun. Tidak adanya fleksura serviks dalam kombinasi fleksura kranial yang berkurang hal tersebut dikaitkan dengan anomali dalam looping jantung tubular ${ }^{(4)}$. Kegagalan atau ketidaksempurnaan mengakibatkan malformasi pada jaringan atau organ terhadap mekanisme perkembangan dapat merusak embrio serta menyebabkan abortus spontan ${ }^{(5,6)}$.

Penggunaan suplemen saat ini sangat populer di masyarakat diantaranya yaitu prolac plus, Extra food hpal, garcia dan spirulina capsules. Kulit buah manggis salah satu contoh suplemen yang cukup banyak dikonsumsi karena mengandung bermacam-macam khasiat. Kulit buah manggis (Garcinia mangostana L.) terdapat xanthone, merupakan antioksidan tingkat tinggi. Xanthone memiliki sifat induksi apoptosis dan antiproliferasi sehingga banyak dimanfaatkan sebagai obat herbal dan antikanker ${ }^{(7)}$. Akan tetapi, jika dikonsumsi secara berlebihan sebagai obat herbal pada kehamilan perlu hati-hati, karena dikhawatirkan dapat melewati barier plasenta dan mengalami biotransformasi sehingga dapat menghasilkan senyawa yang bersifat teratogenik sehingga menimbulkan defek pada saat embriogenesis ${ }^{(8)}$. Pada peneltian sebelumnya yang dilakukan Akao (2008) didapatkan hasil bahwa ekstrak kulit buah manggis dapat menginduksi apoptosis serta dapat menghambat proliferasi sel terutama sel kanker. Oleh karena itu tidak menutup kemungkinan bahwa kulit buah manggis dapat berpengaruh terhadap sel tubuh yang normal ${ }^{(9)}$.

Penelitian bertujuan untuk mengetahui efek pemberian ekstrak kulit buah manggis (Garcinia mangostana L.) menghambat flexi cranial dengan melihat flexi atau tidaknya pada flexi cranial. Hewan coba embrio ayam baik digunakan sebagai model pembelajaran karena dapat menjelaskan informasi mengenai rute yolk sac yaitu ketika masuknya senyawa suatu zat ke dalam yolk sac dapat diserap langsung ke dalam tubuh embrio melalui peredaran darah dan juga menjelaskan informasi secara molekuler maupun genomik tentang perkembangan hematopoietik dan morfogenesis serta abnormalitasnya. 


\section{METODE PENELITIAN}

Penelitian ini merupakan penelitian studi eksperimental in ovo dengan rancangan Randomized Post Test Only Controlled Group Design. Penelitian dilakukan di Laboratorium Anatomi Histologi dan Patologi Anatomi Fakultas Kedokteran Universitas Brawijaya Malang.

\begin{abstract}
Penelitian ini menggunakan hewan coba yaitu telur ayam berembrio yang berusia kurang dari 7 hari pasca oviposition dengan spesies Gallus gallus dari peternakan lokal di daerah Desa Modopuro, Kecamatan Mojosari, Kabupaten Mojokerto, Provinsi Jawa
\end{abstract} Timur.

\begin{tabular}{lr}
\multicolumn{2}{c}{ Pembagian kelompok dan } \\
jumlah sampel & berdasarkan \\
banyaknya & pengulangan pada \\
kelompok & menggunakan \\
perhitungan & sampel dalam
\end{tabular}
kelompok. Telur ayam berembrio dikelompokkan menjadi 4 kelompok. Kelompok kontrol (A) dengan diinjeksi NS $200 \mu \mathrm{L}$, kelompok perlakuan paparan ekstrak kulit buah manggis pada kelompok (B) dengan dosis $100 \mu \mathrm{g} / \mathrm{mL}$, kelompok (C) dengan dosis $150 \mu \mathrm{g} / \mathrm{mL}$, dan kelompok (D) dengan dosis 200 $\mu \mathrm{g} / \mathrm{mL}$. Perlakuan pada penelitian ini dilakukan dengan menginjeksikan ekstrak kulit buah manggis menggunakan disposable sryringe 1 cc hingga mencapai bagian tengah telur (yolk) dengan modifikasi jarum ukuran 23G pada ujung tumpul cangkang telur dalam posisi horizontal yang sebelumnya sudah dilakukan desinfeksi dengan menggunakan alcohol swab dan dilapisi selotip kertas. Selanjutnya ditutup dengan menggunakan plesterin dan selotip kertas. Setelah itu telur dibalik $180^{\circ}$ dari posisi sebelumnya dan dilakukan inkubasi selama 48 jam pada suhu $37,5^{\circ} \mathrm{C}-$ $38,5^{\circ} \mathrm{C}$.

\section{Variabel Penelitian}

Variabel bebas yaitu
pemberian ekstrak kulit buah
manggis (Garcinia mangostana L.)
dalam 3 dosis kelompok perlakuan.
Variabel tergantung yaitu flexi
cranial embrio ayam umur 48 jam.

\section{Pengambilan Bahan Coba}

Sesudah dilakukan inkubasi, telur dipecah dengan mengetukkan bagian dasar telur tanpa merubah posisi telur supaya kuning telur (yolk) tidak pecah. Kemudian telur dipecahkan di atas cawan yang sudah diisi larutan $\mathrm{NaCl} \quad 0,9 \%$ sekitar setengah bagian cawan. Selanjutnya kertas saring yang telah dibentuk bingkai diletakkan di atas permukaan yolk dengan posisi embrio berada di tengah bingkai kertas saring. Setelah itu vitelline membrane yang ada disisi luar bingkai kertas saring digunting dengan gunting mata dan kertas saring diangkat secara perlahanlahan menggunakan pinset lengkung. Pada bingkai kertas saring tersebut, embrio akan terlihat dibagian tengah yang ikut 
menempel di dalam tengah lubang bingkai kertas saring. Bahan coba dicuci pada larutan $\mathrm{NaCl} 0,9 \%$ pada cawan lain dan digoyang-goyangkan beberapa kali untuk membersihkan sisa-sisa yolk yang menempel.

\section{Fiksasi Sampel}

Embrio diletakkan dalam larutan paraformaldehid 4\%. Larutan fiksasi dikatakan sudah masuk ke dalam sampel seluruhnya jika sampel tersebut telah tenggelam di dasar larutan.

\section{Pengamatan Embrio}

Embrio dilakukan pewarnaan HE (Hematoksilin-Eosin) selama 1 hari. Kemudian sampel diamati menggunakan mikroskop stereo perbesaran 20 kali dan dilakukan scan gambar menggunakan mikroskop yang terhubung dengan aplikasi OlyVIA untuk mengamati embrio.

\section{HASIL PENELITIAN}

\section{Flexi Cranial}

Flexi cranial ditandai dengan menekuknya kepala embrio dan penurunan jantung dari cranial ke bawah. Kelompok kontrol flexi cranial kepala embrio telah menekuk dan sudah mengalami penurunan dari cranial ke bawah, persentase flexi cranial pada kelompok perlakuan dosis 1 yaitu $100 \mu \mathrm{g} / \mathrm{mL}$ cenderung lebih tinggi dibanding persentase flexi cranial pada kelompok dengan dosis paparan ekstrak kulit buah manggis yang lebih tinggi. Analisis data untuk menilai pengaruh pemberian ekstrak kulit buah manggis (Garcinia mangostana L.) menghambat flexi cranial dilakukan uji Chi-Square dengan aplikasi SPSS (Statistical Product and Service Solution). Hasil uji Chi-Square untuk menghambat flexi cranial menunjukkan perbedaan yang signifikan dengan $p$-value $0.002 \quad(p<0.05)$, hasil tersebut menunjukkan dosis ekstrak kulit buah manggis memiliki pengaruh terhadap flexi cranial yaitu dapat menghambat flexi cranial. 

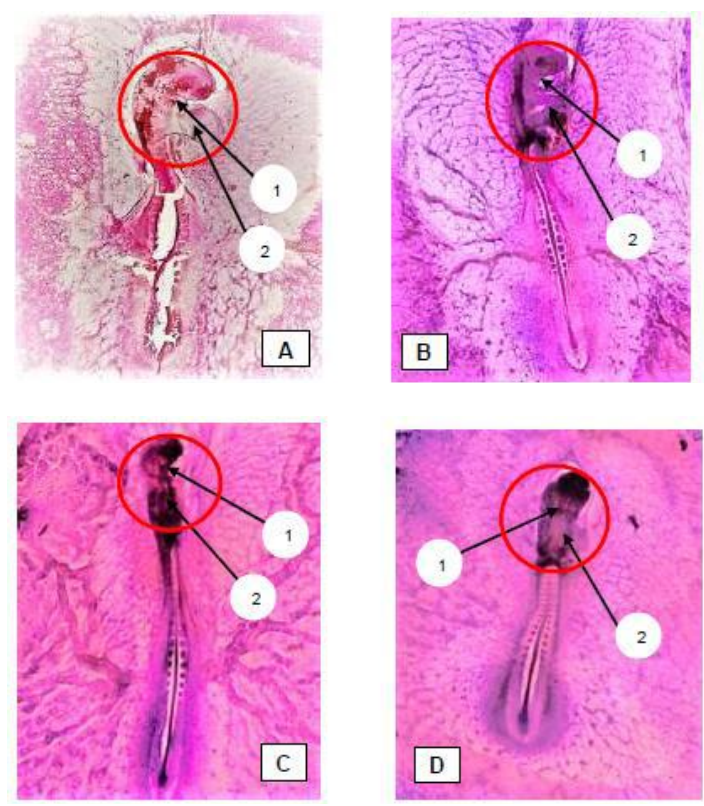

Keterangan gambar: Menunjukkan gambar A normal (kontrol NS $200 \mu \mathrm{L}$ ), yang ditandai dengan terjadi flexi cranial, gambar B (perlakuan $100 \mu \mathrm{g} / \mathrm{mL}$ ), gambar C (perlakuan $150 \mu \mathrm{g} / \mathrm{mL}$ ), gambar D (perlakuan $200 \mu \mathrm{g} / \mathrm{mL}$ ) terdapat kelainan kongenital dengan ditunjukkan pada lingkar merah dengan panah 1 dan 2 bahwa gambar B, gambar C, gambar D tidak terjadi flexi cranial.

\section{Gambar 1. Hasil Penelitian Pada Tiap Kelompok}

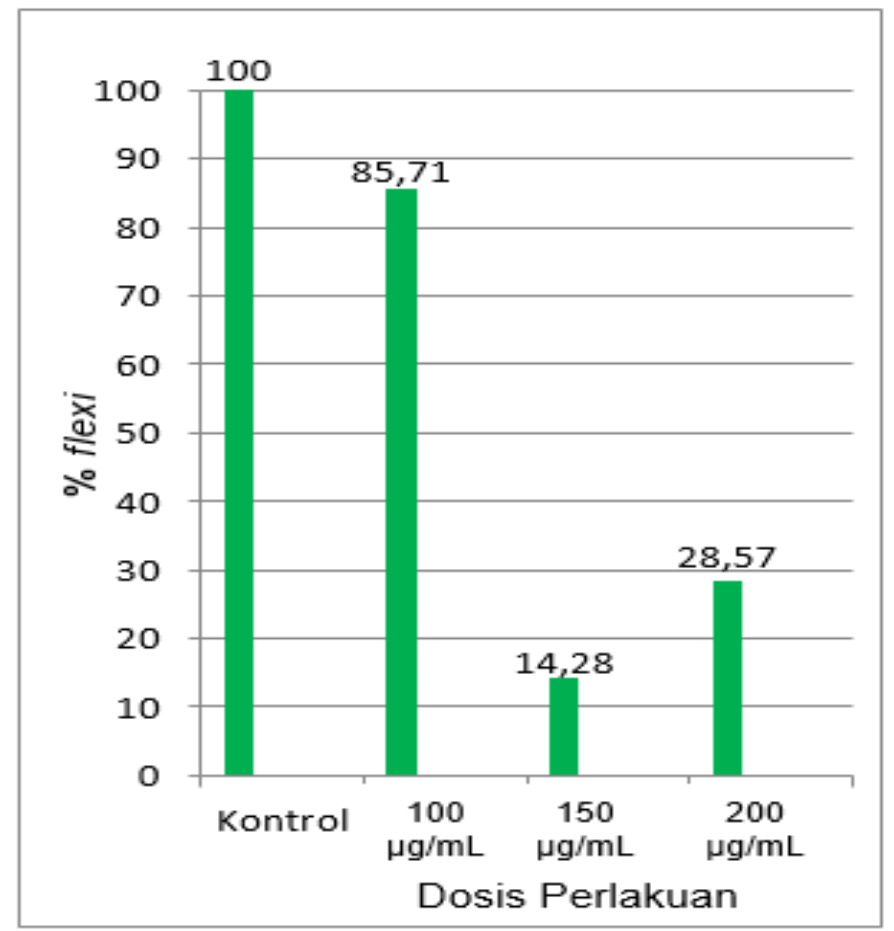

Keterangan gambar: Menunjukkan semakin tinggi dosis ekstrak kulit buah manggis maka akan cenderung tidak flexi yang menandakan terdapat kelainan kongenital terutama pada dosis (perlakuan $150 \mu \mathrm{g} / \mathrm{mL}$ ).

Gambar 2. Diagram Persentase flexi cranial pada embrio ayam umur 48 jam 
PEMBAHASAN

Pengaruh Pemberian Ekstrak
Kulit Buah Manggis (Garcinia
mangostana L.) Menghambat
Flexi Cranial Embrio Ayam Umur
48 Jam

Penelitian ini menggunakan ekstrak kulit buah manggis dengan 3 dosis yang berbeda yaitu 100 $\mu \mathrm{g} / \mathrm{mL}, 150 \mu \mathrm{g} / \mathrm{mL}$ dan $200 \mu \mathrm{g} / \mathrm{mL}$. Penentuan dosis ini didasarkan pada percobaan yang sudah pernah dilakukan sebelumnya oleh Mapanao, dkk (2017), yaitu potensi antiteratogenic kulit buah manggis pada morfologi embrio bebek yang menunjukkan tidak ada kelainan pada dosis $10 \mu \mathrm{g} / \mathrm{mL}, 50 \mu \mathrm{g} / \mathrm{mL}$, dan $100 \mu \mathrm{g} / \mathrm{mL}$ ekstrak kulit buah manggis. Berdasarkan hasil penelitian telah didapatkan pada kelompok A (kontrol), bahwa semua sampel flexi cranial normal semuanya. Pada kelompok perlakuan B, C, dan D, hasil menunjukkan terdapat beberapa keadaan tidak flexi pada sampel masing-masing kelompok. Dari hasil pemaparan tersebut, kemungkinan ekstrak kulit buah manggis menghambat proses flexi cranial.

Flexi cranial merupakan
representasi dari $\begin{array}{r}\text { kemajuan } \\ \text { perkembangan otak serta jantung }\end{array}$
yang ditandai oleh menekuknya
kepala embrio dan penurunan
jantung dari cranial ke bawah.
Terbentuk slight flexi cranial ditandai
oleh menekuknya kepala ke depan
dan posisi jantung juga mulai
turun ${ }^{(4)}$. Flexi cranial terhadap
embrio ayam seharusnya telah

mulai terjadi saat stage 12 Hamburger-Hamilton (45-49 jam) ${ }^{(10)}$. Apabila saat umur tersebut tidak flexi, hal tersebut menunjukkan bahwa ada gangguan dalam proses perkembangannya.

Ekstrak kulit buah manggis diduga menghambat flexi cranial. Ekstrak kulit buah manggis mengandung senyawa alfa mangostin dari xanthone sehingga dapat menginduksi apoptosis sel dengan dimediasi oleh jalur caspase-independent melalui mitokondria dengan pelepasan Endo-G dan penurunan sinyal Wnt mengakibatkan penghambatan pertumbuhan dan kematian sel ${ }^{(9)}$.

Ekstrak kulit buah manggis mengandung senyawa alfa mangostin yang dapat mengganggu Wnt, merupakan protein penting untuk pertumbuhan embrio(11). Sinyal Wnt mengontrol pembentukan awal dari lempeng saraf dan sistem saraf embrionik, termasuk pembentukan dari neural crest. Wnt sangat penting pada tahap perkembangan selanjutnya, mengatur anatomi sitoskeleton neuronal dan diferensiasi sinapsis di otak kecil. Pada embrio, Wnt diperlukan untuk proses pertumbuhan sel, ketika Wnt turun maka kebutuhan protein sel tidak terpenuhi dengan maksimal. Wnt pada pertumbuhan sistem saraf yaitu menghambat ekspresi BMP-4 (Bone Morphogenetic Protein-4) dan TCF ( $T$ Cell Factor) dengan demikian mengaktifkan 
perkembangan saraf, karena ekspresi BMP-4 sebelumnya terbukti menghambat induksi saraf ektoderm dorsal dan TCF juga menghambat induksi saraf ${ }^{(12)}$. Dengan paparan ekstrak kulit buah manggis yang memiliki kandungan senyawa alfa mangostin, sehingga dapat meningkatkan aktivitas ekspresi BMP-4 dan TCF yang bisa jadi mempengaruhi flexi cranial.

Adanya inaktivasi di sel endotel, maka mengakibatkan terhambatnya proses vaskuloangiogenesis. Angiogenesis merupakan vaskularisasi dimana selanjutnya akan terjadi diferensiasi serta penyusunan sel endotel membentuk percabangan pembuluh darah yang baru dari yang lama pada proses pembentukan vaskuloangiogenesis ${ }^{(13)}$. Proses pertumbuhan sel tidak optimal serta peredaran darah menurun sehingga mengganggu perkembangan otak dan jantung, yang seharusnya membutuhkan nutrisi serta oksigen yang adekuat akan tetapi karena hambatan pada saat proses transportasi mengakibatkan proses perkembangannya tidak dapat berjalan dengan baik ${ }^{(14)}$. Paparan ekstrak kulit buah manggis mengandung senyawa alfa mangostin dapat menghambat proses vaskuloangiogenesis, kemudian kemungkinan terjadinya hambatan pada flexi cranial. Sehingga pada usia 48 jam yang seharusnya sudah mengalami flexi menjadi tidak flexi cranial.
Pendukung bahwa ekstrak kulit buah manggis dapat menyebabkan toksisitas dapat diketahui dari penelitian sebelumnya yang telah dilakukan oleh Utami (2015) dengan menggunakan hewan coba mencit hamil, hasil penelitian dijelaskan bahwa pada pemberian dosis $12 \mathrm{mg} / 0,5 \mathrm{~mL}$ seluruh janin mencit mati sehingga dosis tersebut dikatakan toksik ${ }^{(14)}$. Kerentanan pada teratogen sangat bervariasi, tergantung pada tahap perkembangan saat terpapar teratogen. Pada saat fertilisasi melalui pembelahan sel dan pembentukan blastosit sedikit rentan terhadap teratogen, akan tetapi kematian juga dapat terjadi. Hal tersebut diikuti dengan diferensiasi serta organogenesis awal yang mempunyai kerentanan maksimum terhadap teratogen ${ }^{(16)}$.

\section{SIMPULAN}

Berdasarkan hasil penelitian ini didapatkan hasil kesimpulan bahwa pemberian paparan ekstrak kulit buah manggis menghambat flexi cranial dan memberikan hasil yang signifikan.

\section{DAFTAR PUSTAKA}

1. WHO. Congenital Anomalies. (Online), http://www.who.int/mediacentre/fa ctsheets/fs370/en/, 2019. (diakses tanggal 30 Mei 2019)

2. Sadler, T.W. 2012. Langman's Medical Embryology. 12th ed. United States of America: The McGraw-Hill Companies.

3. Rilanto L. 2012. Penyakit Kardiovaskular. FKUI Jakarta. 
4. Goodrum GR, Jacobson AG. Cephalic Flexure Formation in the Chick Embryo. J Exp Zool. 1981; 216:399-408.

5. Aase JM.

Diagnostic dysmorphology. Edisi ke-1. New York \& London: Plenum Medical Book Company. 1990.

6. Indrasanto E, Effendi SH. Pendekatan diagnosis kelainan bawaan menurut klasifikasi. Europeab Registration of Conginetal Anomalies (EUROCAT). 2006

7. Shabella, Rifdah. 2011. "Terapi Kulit Manggis". Klaten: Galmas Publishers.

8. Departemen Kesehatan RI. 2006. Pedoman Pelayanan Farmasi Untuk Ibu Hamil Dan Menyusui. Bakti Husada.

9. Akao, Y., Nakagawa, Y., linuma, M, dan Nozawa, Y. Efek AntiKanker Xanthones dari Pericarps of Manggis. Int J Mol Sci, 2008, 9 (3), 355-370.

10. Bellairs $R$ and Osmond M. The Atlas of Chick Development. Elsevier, Ltd. 2005.

11. Krishnamachary,

B., Subramaniam, D., Dandawate, P., Ponnurangam, S., Srinivasan, P., Ramamoorthy, P., Umar, S., Thomas, SM., Dhar, A., Septer,
S., Weir, SJ., Attard, T., and Anant, S. (2019). Targeting transcription factor TCF4 by $y$ Mangostin, a natural xanthone.vol.10 (54), 5576-5591.

12. Patapoutian, A., Reichardt, LF. 2000. Roles of Wnt proteins in neural development and maintenance. 10(3): 392-399.

13. Frisca, Sardjono, C.T., dan Sandra, $\quad$ F., 2009. ANGIOGENESIS: Patofisiologi dan Aplikasi Klinis, JKM, 8(2): 174-187.

14. Kusumaningrum, E., Rahayu, D, dan Puryatni, A. Efek Supresi Curcumin pada Organogenesis dan Morfogenesis Embrio Ayam Umur 48 Jam. Majalah Kesehatan FKUB. 2015, Volume 2, Nomer 4.

15. Utami, Zahrah Almira Cita. 2015. Efek Pemberian Ekstrak Etanol Kulit Manggis (Garcinia mangostana L.) Terhadap Perkembangan Palatum Pada Mencit Galur Swiss Webster. Undergraduate thesis, Universitas Kristen Maranatha.

16. Wislon, J.G. 1973. Enviroment and Birth Defects. New York and London: Academic Press. Inc 